\title{
SENSITIFITAS KINERJA PASAR MODAL INDONESIA DAN NILAI TUKAR RUPIAH TERHADAP PENYEBARAN KRISIS ASIA ${ }^{1}$
}

\author{
Rini Setyastuti \\ Universitas Atma Jaya Yogyakarta
}

\begin{abstract}
This paper tries to examine the impact of Asia crisis on Indonesian stock market and exchange rate. Despite Engle-Granger procedure and Johansen Criterion, error correction model (ECM) of the two variables are employed to simultaneously estimate the short run and the long run dynamics of the variables. Using monthly data covering the January 1995 to December 2006, empirical results showed that there is a cointegration between variables in the crises period but no cointegration before crises period. The result of ECM estimation proves there is a positive effect on the exchange rate when the Indonesian stock price increased and Thailand exchange rate appreciated. It is because the foreign investors enter the domestic stock market. In the crises period, we can prove that the depreciation of domestic currency and Thailand currency have a positive effect on the stock price in the long run. On the other hand, it is evident that there is a stable parameter of analysis.
\end{abstract}

Keywords : Exchange rate, Stock Price, Interest rate, Error Correction Model

\section{PENDAHULUAN}

Pasar modal amat penting peranannya sebagai pendukung perekonomian suatu negara. Perkembangan perekonomian negara-negara maju dalam sejarahnya amat didukung oleh pendanaan dari pasar modal. Dengan diberlakukannya kebijakan perekonomian terbuka dan pasar bebas dan juga perkembangan teknologi yang pesat, investor menjadi mudah untuk mengakses pasar-pasar modal di seluruh dunia. Fakta yang menyatakan bahwa pasar modal menunjukkan salah satu indikasi sehatnya perekonomian suatu negara, mengisyaratkan betapa pentingnya kondisi pasar modal di suatu negara (Gupta,JP., Allain Chevalier and Fran Sayekt, 1999: 1).

Pasar modal Indonesia yang merupakan bagian dari pasar modal dunia, tidak dapat menghindari pengaruhpengaruh internasional yang mendorong ke arah kointegrasi dan interdependensi atar pasar. Adanya krisis yang menimpa Asia terutama ASEAN dari mulai pertengahan tahun 1997 mempunyai dampak besar pada pasar modal Asean, terutama Indonesia. Turunnya nilai mata uang baht, Thailand, pada tanggal 2 Juli 1997 telah membawa dampak terhadap krisis ekonomi di kawasan Asia Tenggara, khususnya Asean. Dow Jones Industrial Average (indeks saham-saham industri di New York Stock Exchange) turun lebih dari 7 persen pada tanggal 28 Oktober 1997. Sebulan sebelumnya indeks di bursa efek Hongkong turun sebesar 5,8 persen karena spekulasi dan devaluasi mata uang di Asia Tenggara. Banyak orang percaya bahwa penurunan secara spiral berasal dari devaluasi mata uang Thailand, baht, pada tanggal 2 Juli 1997 (New York Times, 4 Juni 1998). Efek domino mencapai Korea dan Jepang. Mata uang Korea, won, turun mencapai limit maksimum dari perdagangan harian, 10 persen, pada tanggal 20 November 1997 mencerminkan bahwa dampak turunnya mata uang Asia dan krisis keuangan benar-benar telah menyebar ke seluruh dunia.

1. Ringkasan dari Hasil Penelitian Dosen Muda 2006, telah dipresentasikan pada acara "Presentasi Dana Penelitian Hibah 2006" di Universitas Atma Jaya Yogyakarta. 
Dampak krisis Asia di Indonesia menyebabkan adanya indikasi kecenderungan kegiatan transaksi di pasar modal menurun. Hal ini dapat dilihat dari perkembangan beberapa indikator di pasar modal seperti Indeks Harga Saham Gabungan (IHSG), nilai kapitalisasi pasar, nilai perdagangan, dan jumlah emiten baru. Hal ini dikarenakan berkurangnya kemampuan emiten dalam memenuhi kewajiban serta menghasilkan laba, sehingga mendorong tekanan jual oleh investor. Situasi ini diperburuk dengan naiknya suku bunga perbankan sehingga mendorong investor untuk lebih senang menyimpan dananya di bank. Di samping itu, turunnya kepercayaan investor dalam dan luar negeri terhadap perekonomian Indonesia semakin memberikan tekanan terhadap pasar modal. Memasuki Agustus 1997, gejolak nilai tukar mempengaruhi pasar modal yang terlihat dari IHSG yang mulai mengalami penurunan yang tajam. Meskipun indeks sempat menguat kembali setelah pemerintah melepaskan batasan investor asing di pasar modal, keadaan ini tidak berlangsung lama karena setelah itu nilai tukar terus mengalami depresiasi yang cukup tajam terhadap dolar. Indeks mengalami titik terendah, yaitu pada tanggal 15 Desember 1997 sebesar 339.536 (Bank Indonesia,1998:121), gambar 1 menunjukkan perkembangan nilai tukar rupiah terhadap dolar Amerika dan indeks harga saham gabungan (IHSG) untuk periode Januari 1996-Februari 2006 .

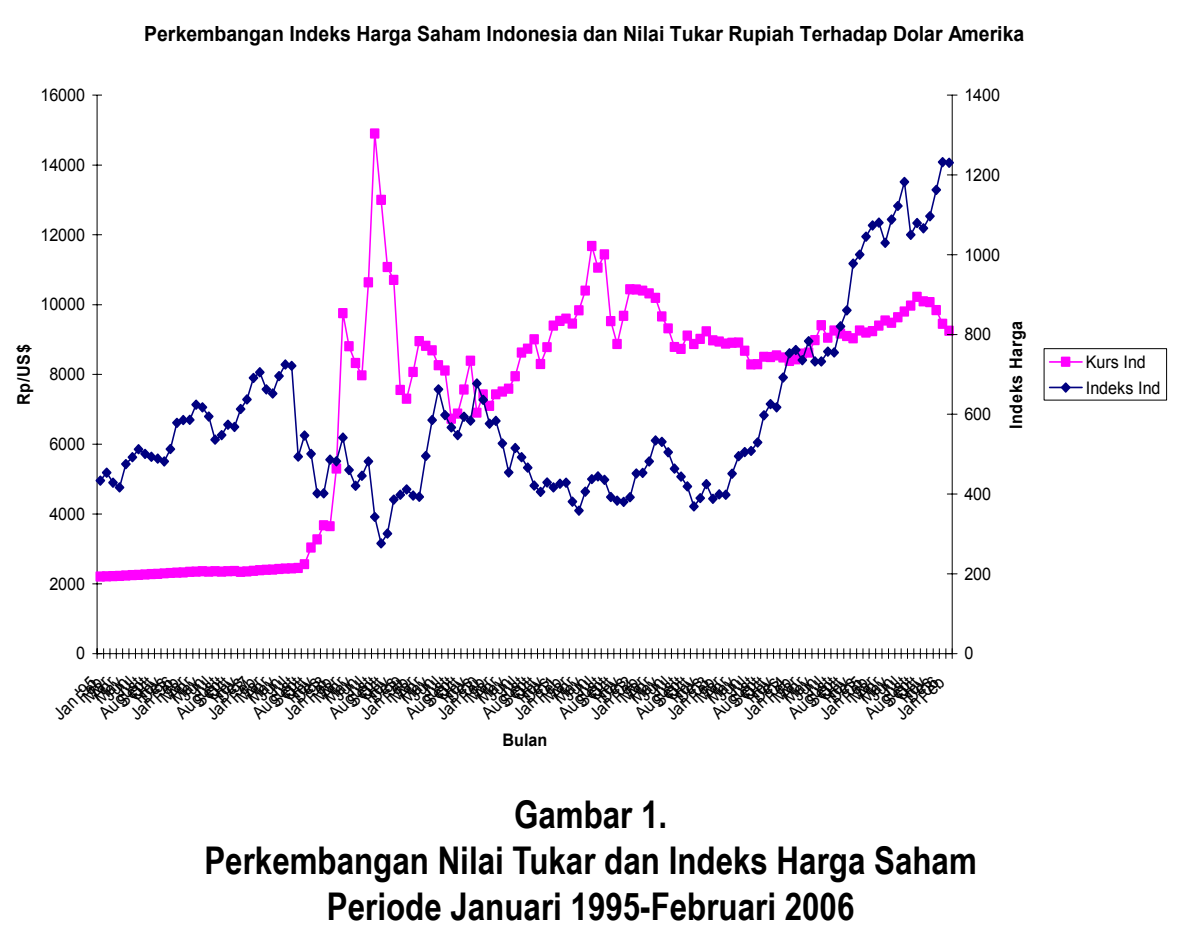

Tidak dapat dipungkiri bahwa krisis Asia yang telah menyebar ke berbagai negara ini mengakibatkan peranan pasar modal yang merupakan alternatif pembiayaan dunia usaha mengalami penurunan. Penurunan ini dapat diakibatkan oleh pengaruh gejolak nilai tukar yang terjadi maupun terjadinya integrasi pasar modal di Asia khususnya Indonesia dan Thailand. Dengan semakin tingginya kecepatan integrasi antarpasar modal melalui dukungan teknologi komputer dan telekomunikasi yang memperlancar informasi antar negara, terjadinya gejolak di pasar yang satu akan segera direspon oleh pasar yang lainnya. Sebagai salah satu negara di kawasan Asia dan menganut sistem perekonomian terbuka, Indonesia tidak dapat menghindar dari pengaruh perubahan yang terjadi di pasar luar negeri. Konsekuensi dari perekonomian yang terbuka ini adalah perlunya semacam penyesuaian dalam perekonomian akibat dari krisis yang terjadi di negara lain. Masalah akan timbul bila penyesuaian tersebut tidak berjalan dengan baik, oleh karena itu prediksi yang akurat mengenai besarnya sensitifitas terhadap pengaruh dari pasar luar negeri, khususnya peristiwa krisis Asia 1997 menjadi semakin penting sebagai pelajaran dalam menyikapi gejolak perekonomian yang mungkin akan terjadi. 


\section{STUDI TERKAIT}

Dalam teori klasik, studi empiris yang dilakukan oleh Cornell (1983) dan Wolff ( 1988 ) menunjukkan adanya hubungan antara nilai tukar dengan aktivitas ekonomi di satu sisi, dan antara harga saham dengan aktivitas ekonomi di sisi lain. Chen, Roll dan Ross ( 1986 ), Mandelker dan Tandon ( 1985 ), Fama (1981) juga menemukan suatu hubungan implisit antara harga saham dan nilai tukar luar negeri ( dalam Ajayi dan Mboja, 1996:194 ).

Ma dan Kao (1990) menggunakan data bulanan untuk enam negara yaitu Inggris, Kanada, Perancis, Jerman Barat, Italia dan Jepang, keenam negara ini dipilih karena pasar mata uang mereka sedikit terkontrol dan mobilitas pasar modal mereka lebih tinggi. Dalam penelitian ini ditemukan bahwa apresiasi mata uang domestik berpengaruh secara negatif pada perilaku harga saham untuk perekonomian yang dominasinya ekspor, dan berpengaruh secara positif pada perekonomian yang dominan mengimpor. Ajayi dan Mboja ( 1996) menggunakan sampel delapan negara yaitu Kanada, Perancis, Jerman, Italia, Jepang, Belanda, Inggris, dan Amerika. Mereka menemukan adanya pengaruh negatif jangka pendek antara harga saham terhadap nilai mata uang domestik karena ekspektasi inflasi yang diisukan di pasar modal. Dalam jangka panjang, meningkatnya harga saham berpengaruh secara positif terhadap nilai mata uang domestik. Di sisi lain, depresiasi mata uang mempunyai pengaruh negatif baik dalam jangka pendek maupun jangka panjang terhadap pasar modal.

Maysami dan Koh (1998) meneliti tentang hubungan keseimbangan jangka panjang antara Indeks Harga Saham di Bursa Singapura dengan variabel ekonomi makro, dan juga hubungan keseimbangan jangka panjang antara indeks saham Singapura, Jepang dan Amerika Serikat. Mereka menemukan bahwa perubahan dua ukuran aktivitas ekonomi riil, produk industri dan perdagangan, tidak berintegrasi pada order yang sama seperti pada perubahan tingkat pasar modal Singapura. Juga ditemukan bahwa perubahan yang terjadi di pasar modal Singapura membentuk hubungan kointegrasi dengan perubahan tingkat harga, jumlah uang beredar, tingkat bunga jangka pendek maupun jangka panjang, dan nilai tukar. Dari penelitian ini juga disimpulkan bahwa pasar modal Singapura berintegrasi secara positif dan signifikan dengan pasar modal Jepang dan Amerika.

Setyastuti (2003), meneliti tentang dampak krisis ekonomi dan kausalitas antara fluktuasi nilai tukar, tingkat bunga dan indeks harga saham, dari penelitian ini ditunjukkan bahwa adanya kinerja pasar modal yang meningkat akan memberikan dampak positif bagi pergerakan nilai tukar rupiah dalam jangka panjang pada saat krisis. Depresiasi nilai tukar domestik mempunyai pengaruh yang buruk terhadap kinerja bursa saham. Di samping itu juga dapat dibuktikan bahwa tingginya suku bunga deposito akan berdampak negatif pada harga saham karena pendapatan dari bunga deposito menjadi lebih menarik dibandingkan dengan pendapatan dari saham.

Penelitian Sukmawati, dkk (2003) tentang krisis ekonomi dan kointegrasi pasar modal membuktikan terjadinya kointegrasi di bursa Asia. Fenomena yang menarik adalah bursa Thailand menjadi bursa yang paling berpengaruh pada periode krisis diantara bursa-bursa yang lainnya.

\section{METODA PENELITIAN}

\subsection{Data}

Data yang digunakan dalam penelitian ini adalah data runtun waktu bulanan dengan periode bulan Januari 1995 sampai dengan Desember 2006. Ada beberapa indikator yang dapat digunakan untuk mengukur tingkat perkembangan di pasar modal, di antaranya adalah indeks harga saham gabungan (composit price index), nilai kapitalisasi pasar, nilai perdagangan, dan jumlah emiten baru. Untuk melihat perkembangan pasar modal, penelitian ini akan menggunakan data indeks harga saham gabungan (composit price index), yang mencakup data pasar modal Indonesia dan Thailand. Untuk data indeks harga saham Thailand dan nilai tukar bath (terhadap dolar Amerika) diambil dari EIU (Economic Intelegent Unit) country data. Untuk data indeks harga saham gabungan Indonesia didapatkan dari publikasi Harian Bisnis Indonesia. Data nilai tukar rupiah (terhadap dolar Amerika) diperoleh dari Bank Indonesia. 


\subsection{Model dan Alat Analisis}

\subsubsection{Model Dasar}

Dalam penelitian pengaruh krisis Asia terhadap nilai tukar rupiah dan harga saham , model dasar yang digunakan adalah :

$S_{t}=f\left(\right.$ Kurs $_{t}$, Kurs $\left._{t}, S T_{t}\right)$, dan

Kurs $_{t}=f\left(S_{t}\right.$, Kurst $\left._{t}, S T_{t}\right)$

di mana :

$\mathrm{S}_{\mathrm{t}}$ adalah indeks harga saham

$\mathrm{ST}_{\mathrm{t}}$ adalah indeks harga saham Thailand

Kurs, adalah nilai tukar rupiah terhadap dolar

Kurs $T_{t}$ adalah nilai tukar bath terhadap dolar

3.2.2. Alat Analisis

Metode yang dipakai mencakup prosedur pengujian yang bertahap. Pengujian tahap pertama adalah apakah data nilai tukar dan indeks harga saham untuk kedua negara stasioner. Jika data telah stasioner, maka dilanjutkan dengan pengujian kointegrasi antara variabel tersebut. Pengujian yang digunakan adalah model koreksi kesalahan (error correction model) yang diturunkan dari fungsi biaya kuadrat tunggal. Untuk melihat apakah ada perbedaan estimasi regresi pada saat sebelum terjadinya krisis dan masa krisis, akan digunakan pengujian Chow (Chow Test) dan metoda Recursive Coefficient Estimate untuk menguji stabilitas persamaan regresi yang diperoleh.

Model koreksi kesalahan (error correction model ) yang digunakan dalam analisis ini diturunkan dari fungsi biaya kuadrat tunggal yang dikenalkan oleh Domowitz dan Elbadawi (1987), yaitu dengan memasukkan vektor yang mempengaruhi variabel tak bebas dengan bobot tertentu dan diasumsikan secara linier tergantung kepada variabel bebas pada komponen biaya penyesuaian. Hasil persamaan akhir dari penurunan model tersebut dikenal sebagai ECM yang baku (standard ECM). Kedua model di bawah ini adalah model yang akan diestimasi dalam penelitian :

(1) DS $_{t}=\gamma_{0}+\gamma_{1}$ DKurs $_{t}+\gamma_{2}$ DKurs T $_{t}+\gamma_{3}$ DST $_{t}+\gamma_{4}$ Kurs $_{t-1}+\gamma_{5}$ KursT $_{t-1}+\gamma_{6}$ ST $_{t-1}+\gamma_{7}\left(\right.$ Kurs $_{t-1}+$ KursT $_{t-1}+$ ST $\left._{t-1}-S_{t-1}\right)$

(2) DKurs $_{t}=\beta_{0}+\beta_{1} \mathrm{DS}_{\mathrm{t}}+\beta_{2}$ DKursT $_{t}+\beta_{3} \mathrm{DST}_{\mathrm{t}}+\beta_{4} \mathrm{~S}_{\mathrm{t}-1}+\beta_{5}$ KursT $_{\mathrm{t}-1}+\beta_{6} \mathrm{ST}_{\mathrm{t}-1}+\beta_{7}\left(\mathrm{~S}_{\mathrm{t}-1}+\right.$ KursT $_{\mathrm{t}-1}+\mathrm{ST}_{\mathrm{t}-1}-$ Kurs $\left._{\mathrm{t}-1}\right)$

di mana :

DS $\quad$ : Besarnya perubahan indeks harga saham (dalam hal ini akan digunakan indeks harga saham gabungan//HSG

DKurs $_{t} \quad$ : Besarnya perubahan kurs (nilai tukar rupiah terhadap dolar Amerika) pada periode $t$

DST $_{t} \quad:$ Besarnya perubahan indeks harga saham Thailand

DKurs $_{t} \quad$ : Besarnya perubahan kurs (nilai tukar Bath terhadap dolar Amerika) pada periode $t$

$\mathrm{S}_{\mathrm{t}-1}$

Kurs $_{\mathrm{t}-1}$

$\mathrm{ST}_{\mathrm{t}-1}$

Kurs $_{\mathrm{t}-1}$

Besarnya indeks harga saham pada periode(bulan) yang lalu

Besarnya kurs pada periode(bulan) yang lalu

Besarnya indeks harga saham Thailand pada periode(bulan) yang lalu

Besarnya nilai tukar Bath terhadap US \$ pada periode(bulan) yang lalu

Besaran koefisien regresi jangka panjang untuk intersep (konstanta) dan variabel bebasnya yang dihitung dari hasil regresi persamaan (1) dan (2) adalah:

(3) $\mathrm{f}_{0}=\gamma_{0} / \gamma_{7} \quad \sim$ koefisien jangka panjang intersep (konstanta)

$\mathrm{f}_{1}=\left(\gamma_{1}+\gamma_{4}\right) / \gamma_{7} \quad \sim$ koefisien jangka panjang nilai tukar rupiah

$\mathrm{f}_{2}=\left(\gamma_{2}+\gamma_{5}\right) / \gamma_{7} \sim$ koefisien jangka panjang nilai tukar bath

$\mathrm{f}_{3}=\left(\gamma_{3}+\gamma_{6}\right) / \gamma_{7} \quad \sim$ koefisien jangka panjang indeks saham Thailand 
(4) $g_{0}=\beta_{0} / \beta_{7} \quad \sim$ koefisien jangka panjang intersep (konstanta)

$g_{1}=\left(\beta_{1}+\beta_{4}\right) / \beta_{7} \sim$ koefisien jangka panjang indeks harga saham

$g_{2}=\left(\beta_{2}+\beta_{5}\right) / \beta_{7} \sim$ koefisien jangka panjang nilai tukar bath

$g_{3}=\left(\beta_{3}+\beta_{6}\right) / \beta_{7} \sim$ koefisien jangka panjang indeks saham Thailand

Dari hasil estimasi model koreksi kesalahan, selanjutnya akan dicoba melihat sensitifitas parameter yang dihasilkan dalam model dengan menggunakan simulasi perubahan kondisi pasar modal dan nilai tukar Thailand. Dalam hal ini shock akan diterapkan dengan meningkatkan atau menurunkan sebesar persentase tertentu pada kondisi pasar modal dan nilai tukar yang dijadikan sebagai variabel eksogen. Simulasi akan dimulai dengan perubahan 1 persen, 5 persen dan 10 persen baik naik maupun turun. Alasan nilai 10 persen digunakan sebagai angka perubahan tertinggi adalah karena di pasar modal biasanya perubahan maksimal sebesar 10 persen adalah perubahan yang sangat fatal karena perubahan di atas angka itu secara psikologis pasar modal tersebut sudah dianggap tidak kredibel.

\section{HASIL DAN PEMBAHASAN}

\subsection{Hasil Pengujian Akar-akar Unit dan Derajat Integrasi}

Uji stasionaritas dapat dilakukan dengan uji akar-akar unit yang dikembangkan oleh Dickey-Fuller (1981), alternatif dari uji Dickey Fuller adalah uji Augmented Dickey Fuller (ADF) yang berusaha untuk meminimumkan autokorelasi. Untuk melihat stasionaritas dengan menggunakan uji DF dan ADF dilakukan dengan membandingkan $t$ (=tau) statistik dari variabel lag variabel dependen dengan nilai kritis DF dan ADF dalam tabel. Perlu diingat di sini bahwa hipotesis nol adalah koefisien dari variabel lag dependen sama dengan nol. Artinya apabila secara statistik nilai koefisien sama dengan nol, maka data tidak stasioner. Hasil pengujian stasioneritas data untuk semua variabel amatan dapat dilihat dalam tabel berikut:

Tabel 1

Hasil Pengujian Akar-akar unit (Unit Roots) dan Derajat Integrasi pada Indeks Harga Saham Indonesia dan Thailand, Nilai Tukar Rupiah dan Bath terhadap Dolar Amerika

\begin{tabular}{lcccc}
\hline \multicolumn{1}{c}{ Variabel } & \multicolumn{2}{c}{ I(0) } & \multicolumn{2}{c}{ I(1) } \\
& DF & ADF & DF & ADF \\
\hline Indeks Harga Saham (Indeksind) & 0,2535 & $-0,5572$ & $-5,3808^{* * *}$ & $-5,0864^{* * *}$ \\
Indeks Harga Saham Thailand (Indeksthai) & $-2,2111$ & $-1,3578$ & $-5,4945^{* * *}$ & $-4,7270^{* * *}$ \\
Kursind & $-1,6962$ & $-1,7991$ & $-4,9933^{* * *}$ & $-4,9623^{* * *}$ \\
Kursthai & $-1,9394$ & $-1,6641$ & $-4,8699^{* * *}$ & $-4,7697^{* * *}$ \\
\hline ***Signifikan pada $\alpha=1 \%$ & & & & \\
Sumber: Hasil Pengolahan & & & &
\end{tabular}

Hasil pengujian menunjukkan bahwa untuk semua variabel tidak stasioner, karena nilai DF maupun ADF berada di daerah penerimaan hipotesis nol (non-stasioneritas) pada tingkat signifikansi 1\% (alfa=1\%) .

Setelah uji akar-akar unit, dilakukan uji derajat integrasi untuk mengetahui pada derajat berapa data yang diamati akan stasioner. Uji ini dilakukan bila pada uji akar-akar unit, data yang diamati ternyata tidak stasioner. Hasil dari uji derajat integrasi juga dapat dilihat pada tabel 1, pada kolom keempat dan kelima. Hasil pengujian derajat integrasi menunjukkan bahwa data pada variabel-variabel yang diamati stasioner pada derajat 1. Dengan demikian dapat dimungkinkan adanya kointegrasi antar variabel tersebut.

\subsection{Hasil Pengujian Kointegrasi}

Seperti yang telah disinggung di muka, setelah diketahui bahwa variabel-variabel terkait dalam pendekatan ini memiliki derajat integrasi yang sama, maka dapat dilakukan uji kointegrasi. Uji kointegrasi dilakukan untuk 
mengetahui apakah akan terjadi keseimbangan antara variabel dalam jangka waktu yang sama. Di samping menggunakan Engle-Granger two step prosedure untuk menguji kointegrasi antar variabel, dalam penelitian ini juga digunakan metode Johansen's ML, yang merupakan uji kointegrasi yang berhubungan dengan konteks Vector Autoregresive (VAR) pada ECM. Hasil estimasi pengujian kointegrasi dengan menggunakan Engle-Granger two step prosedure dapat dilihat pada tabel 2. Dari hasil estimasi yang menggunakan data keseluruhan baik masa sebelum krisis dan setelah krisis, ditunjukkan bahwa terbukti adanya satu persamaan kointegrasi, yaitu besarnya kurs rupiah terhadap dolar sebagai variabel dependen dengan variabel kinerja pasar modal Indonesia (indeks harga saham Indonesia), indeks harga pasar modal Thailand dan nilai tukar Bath Thailand terhadap dolar Amerika sebagai variabel independen. Ini menunjukkan bahwa dalam jangka panjang nilai tukar rupiah terhadap dolar Amerika dipengaruhi oleh besarnya ketiga variabel tersebut yaitu kinerja pasar modal Indonesia (indeks harga saham Indonesia), indeks harga pasar modal Thailand dan nilai tukar Bath Thailand terhadap dolar Amerika. Di samping itu variabel kinerja pasar modal (indeks harga saham Indonesia) dalam jangka panjang tidak terbukti dipengaruhi oleh besarnya fluktuasi nilai tukar rupiah maupun nilai tukar bath terhadap dolar Amerika dan besarnya indeks saham Thailand.

Tabel 2

Hasil Pengujian Kointegrasi dengan menggunakan Engle-Granger two-step prosedure

\begin{tabular}{lll}
\hline \multicolumn{1}{c}{$\begin{array}{c}\text { Variabel } \\
\text { Dependen }\end{array}$} & \multicolumn{1}{c}{ Variabel Independen } & \multicolumn{1}{c}{ ADF untuk Residual } \\
\hline $\begin{array}{l}\text { Indeksind } \\
\text { KursInd }\end{array}$ & IndeksThai, KursInd, KursThai & $-1,402968$ \\
& IndeksInd, IndeksThai, KursThai & $-3,119931^{* * *}$ \\
\hline
\end{tabular}

$\overline{* \star \star}$ Signifikan pada $\alpha=1 \%$

Sumber: Hasil Pengolahan

Dengan tujuan pengujian yang sama, di bawah ini ditunjukkan hasil pengujian kointegrasi dengan menggunakan prosedur Johansen.

Tabel 3

Hasil Pengujian Kointegrasi

Berdasarkan Johansen Criterion

\begin{tabular}{lc}
\hline \multicolumn{1}{c}{ Variabel } & Ho: $r=0$ Ha: $r>=1$ \\
\hline $\begin{array}{l}\text { Indeks Harga Saham (Indeksind), Indeks Harga Saham Thailand } \\
\text { (Indeksthai), Kursind, Kursthai }\end{array}$ & $80.68469^{* \star *}$ \\
${ }^{* \star \star}$ Signifikan pada $\alpha=1 \%$ & \\
Sumber: Hasil Pengolahan &
\end{tabular}

Dari hasil pengujian di atas, dapat dilihat bahwa untuk kointegrasi antar dua variabel ternyata pengujian dengan Johansen Criterion mendukung hasil pengujian dengan menggunakan Engle-Granger two step procedure. Untuk selanjutnya mungkin akan lebih detail apabila dilakukan analisis berdasarkan pada perbedaan waktu sebelum dan sesudah terjadinya krisis ekonomi di Asia.

Untuk melihat apakah ada perbedaan hasil estimasi persamaan regresi pada periode sebelum krisis dan pada saat krisis, dapat digunakan pengujian Chow (Chow Test) yaitu untuk membuktikan apakah estimasi persamaan garis regresi selama periode sebelum krisis dan pada masa krisis berbeda (Gujarati, 2003 : 275-278). Dalam analisa ini diasumsikan perubahan estimasi persamaan regresi untuk pengujian kointegrasi periode krisis 
ekonomi dimulai pada saat kondisi negara di Asia secara umum bersama-sama memasuki masa krisis yaitu pada bulan Agustus 1997. Pada masa itu nilai tukar mata uang negara-negara Asia terhadap nilai dolar Amerika ratarata mulai mengalami penurunan.

Hasil pengujian kointegrasi dengan menggunakan Engle-Granger two-step prosedure dengan membedakan antara masa sebelum krisis dan sesudah krisis dapat dilihat pada tabel berikut :

Tabel 4.

Hasil Pengujian Kointegrasi dengan menggunakan Engle-Granger two-step prosedure masa sebelum krisis dan masa krisis

\begin{tabular}{llcc}
\hline \multirow{2}{*}{ Variabel Dependen } & Variabel Independen & \multicolumn{2}{c}{ ADF untuk Residual } \\
\cline { 3 - 4 } & & $\begin{array}{c}\text { Masa sebelum } \\
\text { krisis }\end{array}$ & Masa krisis \\
\hline IndeksInd & $\begin{array}{l}\text { IndeksThai, KursInd, KursThai } \\
\text { IndeksInd, IndeksThai, } \\
\text { KursInd }\end{array}$ & $-3,7469^{* * *}$ & $-1,3638$ \\
& KursThai & $-3,4748^{* * *}$ & $-3,6364^{* * *}$ \\
\hline
\end{tabular}

***Signifikan pada $\alpha=1 \%$

Sumber: Hasil Pengolahan

Berdasarkan tabel 4 dapat dilihat bahwa pada masa sebelum terjadinya krisis ekonomi maupun setelah terjadinya krisis besarnya kurs dalam jangka panjang terbukti dipengaruhi oleh besarnya indeks harga saham Indonesia maupun Thailand dan nilai tukar Bath terhadap dolar Amerika. Ini menjadi hal yang sangat menarik karena pada saat sebelum krisis Indonesia menganut sistem nilai tukar mengambang terkendali, tetapi ternyata fluktuasinya juga dapat dipengaruhi oleh besarnya nilai tukar Bath terhadap dolar, di samping dipengaruhi oleh kinerja pasar saham di negeri sendiri ataupun pasar saham Thailand. Dari hasil ini tidak diragukan lagi pada saat krisis pengaruh ke tiga variabel ini (indeks harga saham Indonesia dan Thailand, dan nilai tukar Bath ) masih tetap signifikan. Meskipun ada satu persamaan yang hasilnya tidak konsisten dengan hasil pengujian Granger, hasil pengujian kointegrasi berdasarkan Johansen Criterion dapat dikatakan mendukung hasil yang diperoleh dengan menggunakan metode di atas. Hasil pengujian dengan Johansen Criterion dapat dilihat pada tabel 5 berikut.

Tabel 5

Hasil Pengujian Kointegrasi Berdasarkan Johansen Criterion Masa Sebelum Krisis dan Setelah Krisis

\begin{tabular}{lcc}
\hline \multicolumn{1}{c}{ Variabel } & \multicolumn{2}{c}{ Ho: $r=0$ Ha: $>=1$} \\
\cline { 2 - 3 } & $\begin{array}{c}\text { Masa sebelum } \\
\text { krisis }\end{array}$ & Masa krisis \\
\hline Indeks Harga Saham (Indeksind), Indeks Harga & $67.54178^{\star * *}$ & $83.68576^{* * *}$ \\
Saham Thailand (Indeksthai), Kursind, Kursthai & & \\
***Signifikan pada $\alpha=1 \%$, & \\
Sumber: Hasil Pengolahan &
\end{tabular}

Dari tabel 5 di atas ditunjukkan bahwa dengan menggunakan pengujian Johansen, secara umum pada masa sebelum dan setelah terjadinya krisis ekonomi, variabel-variabel yang diamati terbukti terkointegrasi. Ini mengindikasikan adanya kemungkinan perilaku pasar yang konsisten pada masa sebelum dan sesudah krisis. Salah satu kemungkinan yang terjadi adalah pelaku di pasar modal mengambil keuntungan dengan memanfaatkan perbedaan penurunan nilai mata uang domestik antar negara, dan ini tetap berlangsung secara intensif pada saat 
terjadinya krisis. Mereka akan melakukan spekulasi dengan membeli atau menjual saham yang diperdagangkan di beberapa bursa dengan memperhitungkan keuntungan yang diakibatkan oleh fluktuasi nilai tukar di negara tertentu. Perilaku arbitrage yang mereka lakukan kemungkinan akan berdampak pada pencapaian kondisi keseimbangan dalam jangka panjang antar variabel. Fenomena ini mengisyaratkan bahwa perilaku spekulasi yang didasarkan pada pergerakan fluktuasi nilai tukar di kedua bursa akan menguntungkan dalam jangka pendek maupun dalam jangka panjang, mengingat variabel-variabel yang diamati tersebut saling berkointegrasi.

\subsection{Estimasi Persamaan dengan Error Correction Model (ECM)}

Tabel 6, 7 dan 8 masing-masing menyajikan hasil estimasi persamaan regresi hasil estimasi model persamaan koreksi kesalahan (Error Correction Model/ECM) dengan menggunakan data keseluruhan, data sebelum krisis dan data setelah krisis. Secara umum hubungan jangka pendek $d$ an jangka panjang yang ditunjukkan dalam hasil estimasi persamaan-persamaan di bawah ini ada beberapa yang signifikan, yang berarti beberapa dari hasil estimasi mendukung hasil pengujian kointegrasi baik menggunakan Engle-Granger Procedur ataupun Johansen Criterion.

Tabel 6

Hasil Estimasi Persamaan Regresi dengan ECM Data Keseluruhan

\begin{tabular}{|c|c|c|c|c|c|c|}
\hline \multicolumn{2}{|c|}{ Variabel Dependen-independen } & Koef. & Sd. Error & T-stat & $\mathbf{F}$ & $\mathbf{R}^{2}$ \\
\hline \multirow[t]{8}{*}{$\mathrm{D}$ (Kursind) } & $\mathrm{C}$ & -1465.521 & 729.7778 & -2.008175 & $10.69134^{* * *}$ & 0.374498 \\
\hline & D(Indeksthai) & -0.436545 & 1.179925 & -0.369977 & & \\
\hline & $\mathrm{D}($ Indeksind $)$ & -1.215496 & 1.325893 & -0.916738 & & \\
\hline & D(Kursthai) & -95.48507 & 35.93929 & $-2.656843^{* *}$ & & \\
\hline & Indeksthai(-1) & 0.663673 & 0.392384 & 1.691385 & & \\
\hline & Indeksind(-1) & -0.278664 & 0.307293 & -0.906836 & & \\
\hline & Kursthai(-1) & 35.11834 & 15.64808 & 2.244259 & & \\
\hline & Ectkurs(-1) & -0.286009 & 0.037192 & $-7.690056^{\star \star *}$ & & \\
\hline \multirow[t]{8}{*}{$\mathrm{D}$ (Indeksind) } & C & -76.49875 & 51.22964 & -1.493252 & $5.440945^{* *}$ & 0.233536 \\
\hline & D(Indeksthai) & 0.383392 & 0.071583 & $5.355879^{* * *}$ & & \\
\hline & $\mathrm{D}($ Kursind $)$ & -0.005494 & 0.005993 & -0.916738 & & \\
\hline & D(Kursthai) & -4.323080 & 2.453303 & -1.762146 & & \\
\hline & Indeksthai(-1) & 0.042317 & 0.023015 & 1.838670 & & \\
\hline & Kursind(-1) & -0.002334 & 0.002863 & -0.815234 & & \\
\hline & Kursthai(-1) & 2.048644 & 1.443844 & 1.418882 & & \\
\hline & Ectind(-1) & -0.001376 & 0.021976 & -0.062593 & & \\
\hline
\end{tabular}

***Signifikan pada $\alpha=1 \%,{ }^{*}$ * Signifikan pada $\alpha=5 \%,{ }^{*}$ Signifikan pada $\alpha=10 \%$

Sumber: Hasil Pengolahan 
Tabel 7.

Hasil Estimasi Persamaan Regresi dengan ECM

Data Sebelum Krisis

\begin{tabular}{llrrrrr}
\hline \multicolumn{2}{c}{ Variabel Dependen-independen } & Koef. & Sd. Error & \multicolumn{1}{c}{ T-stat } & F & $\mathbf{R}^{2}$ \\
\hline $\mathrm{D}$ (Kursind) & C & -11.89461 & 220.3261 & -0.053986 & 1.411148 & 0.309870 \\
& D(Indeksthai) & -0.022391 & 0.021086 & -1.061852 & & \\
& D(Indeksind) & 0.034042 & 0.058010 & 0.586831 & & \\
& D(Kursthai) & 7.463615 & 11.13650 & 0.670194 & & \\
& Indeksthai(-1) & 0.002269 & 0.018449 & 0.122983 & & \\
& Indeksind(-1) & 0.008442 & 0.035063 & 0.240766 & & \\
& Kursthai(-1) & 0.459218 & 8.368975 & 0.054872 & & \\
& Ectkurs(-1) & -0.212230 & 0.077809 & $-2.727561^{* *}$ & & \\
\hline D(Indeksind) & C & 356.9738 & 775.2299 & 0.460475 & 0.823635 & 0.207648 \\
& D(Indeksthai) & 0.006549 & 0.078831 & 0.083072 & & \\
& D(Kursind) & 0.452729 & 0.771481 & 0.586831 & & \\
& D(Kursthai) & -18.91358 & 40.82617 & -0.463271 & & \\
& Indeksthai(-1) & -0.034937 & 0.064186 & -0.544314 & & \\
& Kursind(-1) & 0.029018 & 0.186321 & 0.155744 & & \\
& Kursthai(-1) & -15.07053 & 34.47074 & -0.437198 & & \\
& Ectind(-1) & -0.451471 & 0.204323 & $-2.209599^{* *}$ & & \\
\hline
\end{tabular}

${ }^{* \star \star}$ Signifikan pada $\alpha=1 \%,{ }^{*}$ * Signifikan pada $\alpha=5 \%,{ }^{*}$ Signifikan pada $\alpha=10 \%$

Sumber: Hasil Pengolahan

Tabel 8.

Hasil Estimasi Persamaan Regresi dengan ECM Data Periode Krisis

\begin{tabular}{|c|c|c|c|c|c|c|}
\hline \multicolumn{2}{|c|}{ Variabel Dependen-independen } & Koef. & Sd. Error & T-stat & $\mathrm{F}$ & $\mathbf{R}^{2}$ \\
\hline $\mathrm{D}$ (Kursind) & $\begin{array}{l}C \\
D \text { (Indeksthai) } \\
D \text { (Indeksind) } \\
D \text { (Kursthai) } \\
\text { Indeksthai(-1) } \\
\text { Indeksind(-1) } \\
\text { Kursthai(-1) } \\
\text { Ectkurs(-1) }\end{array}$ & $\begin{array}{r}-2705.464 \\
-1.989520 \\
-0.196782 \\
-88.49871 \\
0.537027 \\
-0.158753 \\
64.66981 \\
-0.309466\end{array}$ & $\begin{array}{l}1178.348 \\
2.154055 \\
1.790908 \\
44.33018 \\
1.067435 \\
0.674236 \\
26.57586 \\
0.046487\end{array}$ & $\begin{array}{r}-2.295980^{* *} \\
-0.923616 \\
-0.109878 \\
-1.996354^{* *} \\
0.503100 \\
-0.23557 \\
2.433404^{* *} \\
-6.65700^{* * *}\end{array}$ & $9.29499^{* * *}$ & 0.406491 \\
\hline $\mathrm{D}$ (Indeksind) & $\begin{array}{l}\text { C } \\
\text { D(Indeksthai) } \\
\mathrm{D} \text { (Kursind) } \\
\mathrm{D} \text { (Kursthai) } \\
\text { Indeksthai(-1) } \\
\text { Kursind(-1) } \\
\text { Kursthai(-1) } \\
\text { Ectind(-1) }\end{array}$ & $\begin{array}{r}-72.11768 \\
0.728410 \\
-0.000646 \\
-4.051661 \\
0.060015 \\
-0.002006 \\
1.641150 \\
-0.074226\end{array}$ & $\begin{array}{l}68.81960 \\
0.098882 \\
0.005877 \\
2.558604 \\
0.028168 \\
0.002868 \\
1.709072 \\
0.043074\end{array}$ & $\begin{array}{r}-1.047923 \\
7.366424^{* * *} \\
-0.109878 \\
-1.583543 \\
2.130644 \\
-0.699392 \\
0.960258 \\
-1.72324^{* * *}\end{array}$ & $10.1057^{* \star *}$ & 0.426812 \\
\hline
\end{tabular}

${ }^{* \star \star}$ Signifikan pada $\alpha=1 \%,{ }^{* *}$ Signifikan pada $\alpha=5 \%,{ }^{*}$ Signifikan pada $\alpha=10 \%$

Sumber: Hasil Pengolahan

Dari tabel 6, 7 dan 8 dapat ditunjukkan persamaan ECM yang menunjukkan pengaruh indeks harga saham Thailand (INDEKSTHAI), indeks harga saham Indonesia (INDEKSIND) dan nilai tukar bath terhadap dolar Amerika 
(KURSTHAI) terhadap nilai tukar rupiah terhadap dolar Amerika (KURSIND). Dengan data keseluruhan besarnya kurs bath, indeks harga saham Indonesia maupun Thailand terbukti berpengaruh secara signifikan terhadap besarnya kurs rupiah terhadap dolar dalam jangka panjang, ini dinyatakan dengan signifikannya koefisien lag dari ECT-nya (Error Correction Term), dalam jangka pendek hanya variabel kurs bath terhadap dolar saja yang terbukti berpengaruh terhadap fluktuasi kurs rupiah. Terjadinya depresiasi mata uang bath terhadap dolar Amerika, dapat mengakibatkan depresiasi mata uang rupiah terhadap dolar. Hal ini menunjukkan bahwa mata uang rupiah memang rentan terhadap perubahan mata uang negara lain. Efek penularan ini menjadi semakin jelas pada saat krisis terjadi di Asia, dampak krisis ini menjadi semakin hebat di Indonesia. Pada hasil estimasi model yang sama juga ditunjukkan bahwa pengujian Goodness of fit yang dinyatakan dalam nilai $F$ statistik juga terbukti signifikan, di samping itu nilai koefisien determinasi sebesar 0.374498 menunjukkan bahwa besarnya variabel kurs rupiah dapat dijelaskan oleh besarnya indeks harga saham Thailand, indeks saham Indonesia, dan nilai tukar bath adalah sebesar 37.4498\%. Untuk data sebelum terjadinya krisis ditunjukkan bahwa pengujian Goodness of fit untuk kedua estimasi persamaan yang dinyatakan dalam nilai F statistik terbukti tidak signifikan. Untuk itu kedua persamaan ini tidak dapat dianalisis lebih lanjut, meskipun nilai koefisien ECT-nya (Error Correction Term) significan.

Hasil estimasi dengan menggunakan data setelah terjadinya krisis ekonomi menunjukkan hasil estimasi yang sama dengan hasil estimasi ketika digunakan data secara keseluruhan. Terjadinya depresiasi mata uang bath terhadap dolar Amerika, dapat mengakibatkan depresiasi mata uang rupiah terhadap dolar. Nilai koefisien determinasi sebesar 0.406491 menunjukkan bahwa besarnya variabel kurs rupiah dapat dijelaskan oleh besarnya indeks harga saham Thailand, indeks saham Indonesia, dan nilai tukar bath adalah sebesar $40.6491 \%$.

Dalam model persamaan pengaruh indeks harga saham Thailand (INDEKSTHAI), nilai tukar rupiah terhadap dolar Amerika (KURSIND) dan nilai tukar bath terhadap dolar Amerika (KURSTHAI) terhadap indeks harga saham Indonesia (INDEKSIND), dengan menggunakan data secara keseluruhan terbukti tidak berpengaruh secara signifikan dalam jangka panjang. Hal ini dinyatakan dengan tidak signifikannya koefisien lag dari ECT-nya (Error Correction Term), dalam jangka pendek hanya variabel indeks harga saham Thailand saja yang terbukti berpengaruh terhadap fluktuasi indeks harga saham Indonesia. Ini menunjukkan bahwa pasar modal Indonesia memang telah menjadi bagian dari pasar modal negara lain. Angka koefisien yang positif menunjukkan bahwa meningkatnya kinerja pasar modal di Thailand dapat berpengaruh meningkatnya kinerja di pasar modal Indonesia. Pada hasil estimasi model yang sama juga ditunjukkan bahwa pengujian Goodness of fit yang dinyatakan dalam nilai $F$ statistik juga terbukti signifikan, di samping itu nilai koefisien determinasi sebesar 0.233536 menunjukkan bahwa besarnya variabel indeks saham Indonesia dapat dijelaskan oleh besarnya indeks harga saham Thailand, kurs rupiah, dan nilai tukar bath adalah sebesar $23.3536 \%$.

Dalam model persamaan pengaruh indeks harga saham Thailand (INDEKSTHAI), nilai tukar rupiah terhadap dolar Amerika (KURSIND) dan nilai tukar bath terhadap dolar Amerika (KURSTHAI) terhadap indeks harga saham Indonesia (INDEKSIND) dengan menggunakan periode pengamatan setelah terjadinya krisis menunjukkan hal yang agak berbeda dengan hasil estimasi dengan data keseluruhan. Besarnya kurs bath maupun kurs rupiah dan indeks harga saham Thailand terbukti berpengaruh secara signifikan terhadap besarnya indeks harga saha, Indonesia dalam jangka panjang. Hal ini dinyatakan dengan signifikannya koefisien lag dari ECT-nya (Error Correction Term), sama dengan hasil estimasi di atas dalam jangka pendek variabel indeks harga saham Thailand juga terbukti berpengaruh terhadap fluktuasi indeks harga saham Indonesia. Angka koefisien yang positif menunjukkan bahwa meningkatnya kinerja pasar modal di Thailand dapat berpengaruh meningkatnya kinerja di pasar modal Indonesia. Penemuan ini mendukung hasil penelitian Sukmawati, dkk. (2003 ) yang menyatakan bahwa krisis Asia yang dimulai dari Thailand memang sangat berdampak pada bursa di negara-negara sekitarnya seperti Malaysia, Philiphina, dan Indonesia. Pada hasil estimasi model yang sama juga ditunjukkan bahwa pengujian Goodness of fit yang dinyatakan dalam nilai $\mathrm{F}$ statistik juga terbukti signifikan, di samping itu nilai koefisien determinasi sebesar 0.426812 menunjukkan bahwa besarnya variabel indeks saham Indonesia dapat dijelaskan oleh besarnya indeks harga saham Thailand, kurs rupiah, dan nilai tukar bath adalah sebesar $42.6812 \%$. 
Tabel 9

\title{
Estimasi Jangka Panjang Model Koreksi Kesalahan (ECM)
}

\author{
Persamaan Jangka Panjang Data Keseluruhan \\ Kursind $=5124.038+5.224$ Indeksind -0.794 Indeksthai +211.06 Kursthai \\ Persamaan Jangka Panjang Data Setelah Krisis \\ Kursind $=8742.36+0.9$ Indeksind +4.586 Indeksthai -77 Kursthai \\ Indeksind $=971.58+0.035$ Kursind -10.62 Indeksthai +32.475 Kursthai
}

Sumber: Hasil Perhitungan, tidak dilampirkan

Dari tabel 9 ditunjukkan estimasi persamaan jangka panjangnya. Tidak semua persamaan diestimasi persamaan jangka panjangnya karena tidak semua persamaan membuktikan hubungan jangka panjang. Dari data keseluruhan dapat dilihat bahwa dalam jangka panjang, meningkatnya indeks harga Indonesia sebesar satu point akan mengakibatkan perubahan nilai tukar rupiah sebesar 5.22 rupiah, meningkatnya indeks harga Thailand sebesar satu point akan mengakibatkan menguatnya nilai tukar rupiah sebesar 0.794 rupiah, dan terjadinya depresiasi nilai tukar bath sebesar satu bath akan berdampak pada depresiasi nilai tukar rupiah sebesar 211.6 rupiah. Untuk persamaan jangka panjang data setelah adanya krisis tahun 1997 menunjukkan bahwa meningkatnya indeks harga Indonesia sebesar satu point akan mengakibatkan perubahan nilai tukar rupiah sebesar 0.9 rupiah, meningkatnya indeks harga Thailand sebesar satu point akan mengakibatkan meningkatnya nilai tukar rupiah sebesar 4.586 rupiah, dan terjadinya depresiasi nilai tukar bath sebesar satu bath akan berdampak pada menguatnya nilai tukar rupiah sebesar 77 rupiah.

Dari hasil analisis di atas ditunjukkan bahwa kinerja pasar modal Indonesia dan nilai tukar rupiah sangat rentan terhadap perubahan situasi di negara lain. Kondisi perekonomian Indonesia tidak dapat bertahan dengan terjadinya krisis Asia. Nilai estimasi jangka panjang menunjukkan bahwa kinerja perekonomian yang meliputi kinerja pasar modal dan nilai tukar sensitif dengan perubahan perekonomian di negara tetangga. Di bawah ini juga akan ditunjukkan hasil pengujian stabilitas untuk koefisien regresi ketiga persamaan di atas, baik menggunakan data keseluruhan maupun data setelah krisis. Selanjutnya hasil temuan ini akan diuji kembali dengan menggunakan analisis sensitifitas dengan memasukkan shock variabel krisis untuk negara Thailand yaitu indeks harga Thailand dan nilai tukar bath.
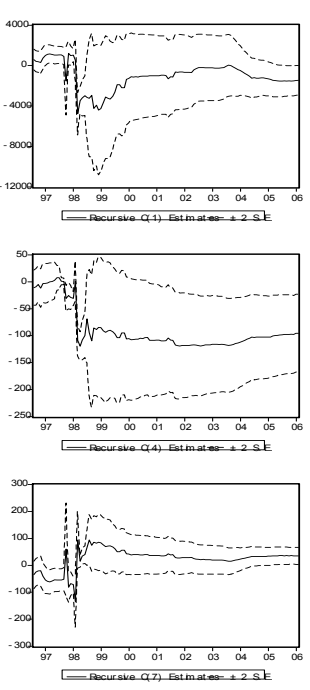

Gambar 2.
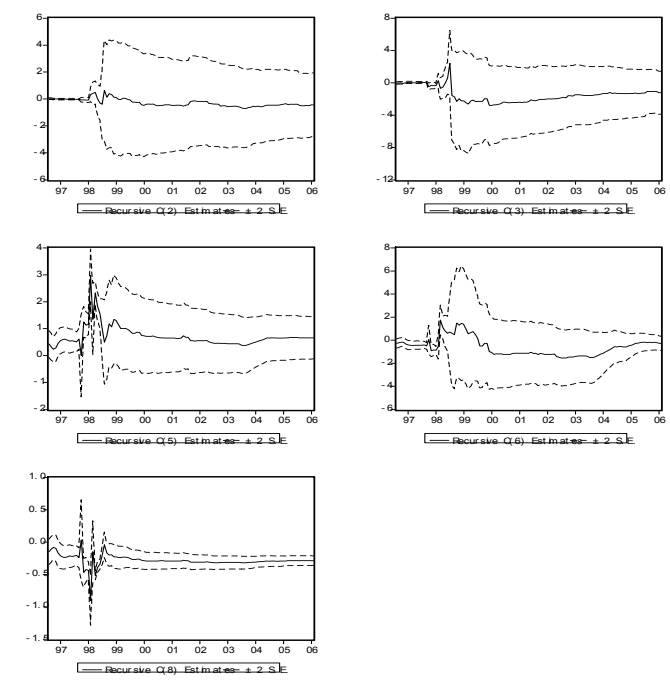

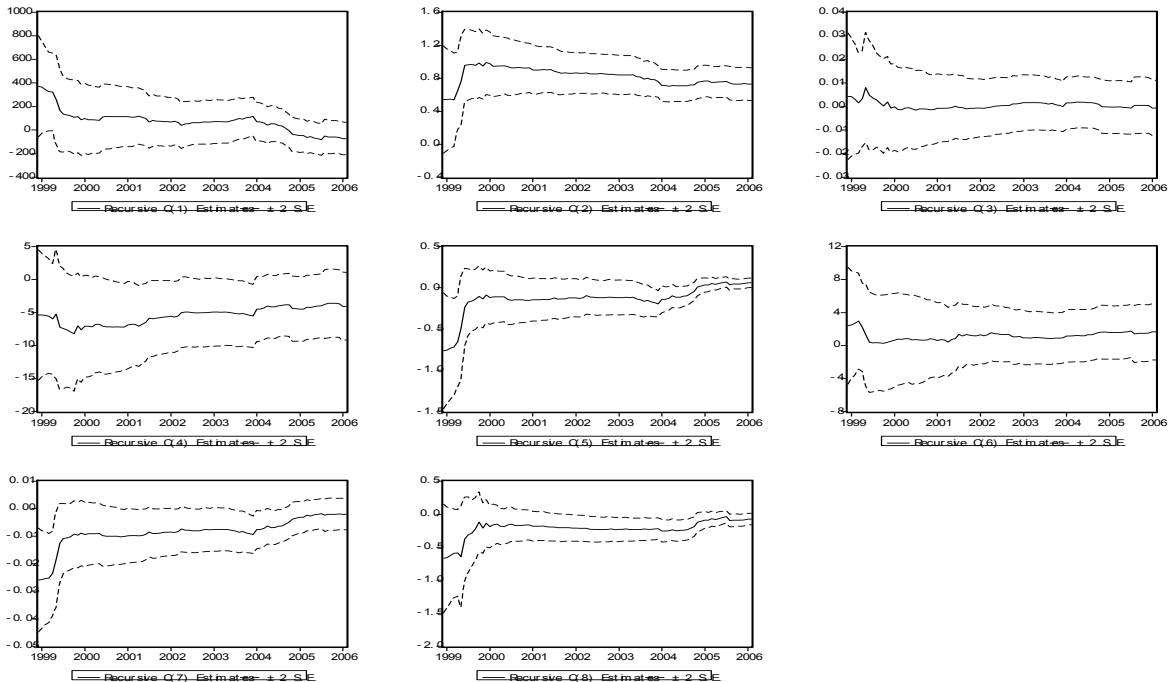

Gambar 3.

Pengujian Stabilitas Koefisien Regresi ECM dengan Data Setelah Krisis
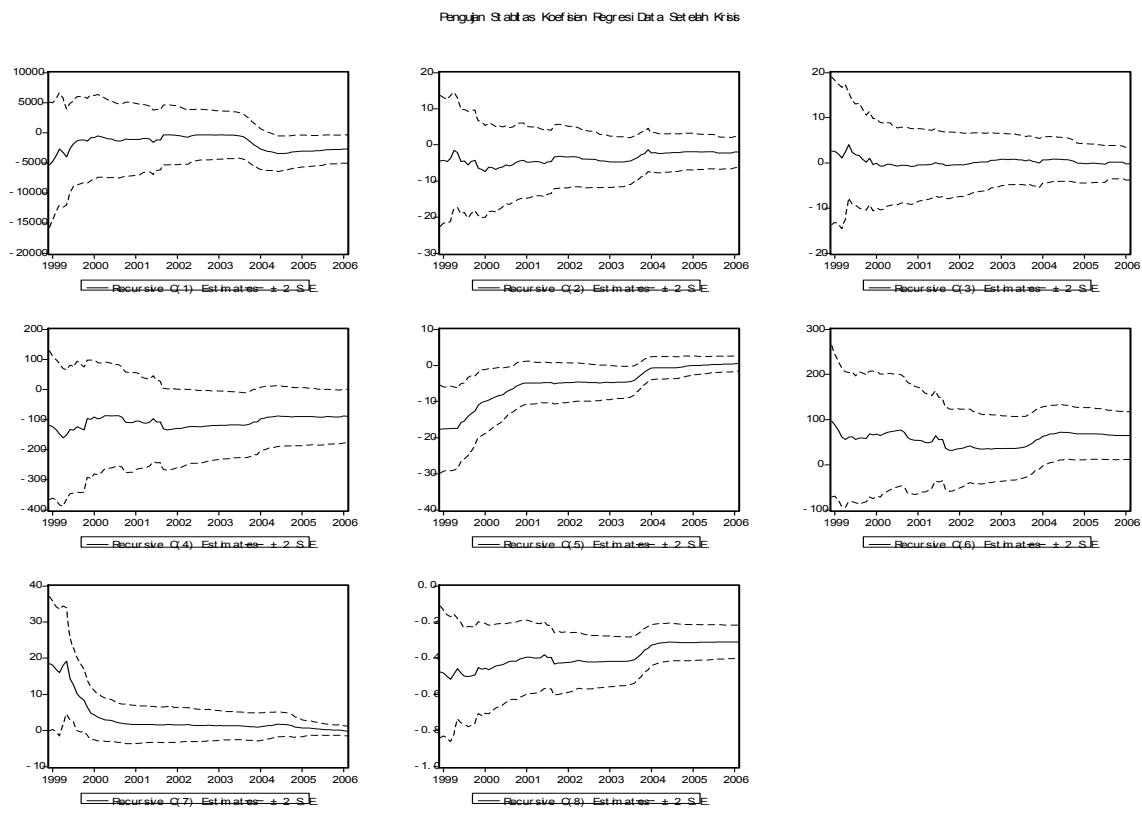

Gambar 4.

\section{Pengujian Stabilitas Koefisien Regresi ECM dengan Data Setelah Krisis}

\subsection{Analisis Sensitifitas dengan Perhitungan Elastisitas Hasil Estimasi Persamaan Jangka Panjang}

Dengan menghitung besarnya elastisitas untuk setiap persamaan dapat diketahui juga seberapa besar pengaruh variabel independen terhadap variabel dependennya. Tabel di bawah ini merupakan hasil perhitungan elastisitas hasil estimasi persamaan jangka panjang pengaruh indeks harga saham Thailand, nilai tukar bath dan 
indeks harga saham Indonesia terhadap nilai tukar rupiah baik dengan data keseluruhan maupun data setelah krisis. Juga ditunjukkan juga elastisitas hasil estimasi persamaan jangka panjang pengaruh indeks harga saham Thailand, nilai tukar bath dan nilai tukar rupiah, terhadap indeks harga saham Indonesia dengan data setelah krisis

Tabel 10.

Hasil Perhitungan Elastisitas

\begin{tabular}{lcc}
\hline \multicolumn{2}{c}{ Variabel Dependen-Independen } & Elastisitas \\
\hline KURSIND & INDEKSTHAI & -0.0643 \\
(data keseluruhan) & INDEKSIND & 4.283 \\
& KURSTHAI & 1.0834 \\
INDEKSIND & INDEKSTHAI & -6.561 \\
(data setelah krisis) & KURSIND & 0.2755 \\
& KURSTHAI & 1.0691 \\
KURSIND & INDEKSTHAI & 0.3599 \\
(data setelah krisis) & INDEKSIND & 0.1143 \\
& KURSTHAI & -0.0306 \\
\hline
\end{tabular}

Dari hasil perhitungan elastisitas di atas, diketahui bahwa meskipun angka elastisitas ada beberapa yang lebih kecil daripada satu, tetapi ini harus tetap diperhatikan. Dari data keseluruhan dapat dilihat bahwa dalam jangka panjang, meningkatnya indeks harga Indonesia sebesar satu persen akan mengakibatkan perubahan nilai tukar rupiah sebesar 4.283 persen, meningkatnya indeks harga Thailand sebesar satu persen akan mengakibatkan menguatnya nilai tukar rupiah sebesar 0.0643 persen, dan terjadinya depresiasi nilai tukar bath sebesar satu bath akan berdampak pada depresiasi nilai tukar rupiah sebesar 1.0834 persen. Untuk persamaan jangka panjang data setelah adanya krisis tahun 1997 menunjukkan bahwa meningkatnya indeks harga Indonesia sebesar satu persen akan mengakibatkan perubahan nilai tukar rupiah sebesar 0.1143 persen, meningkatnya indeks harga Thailand sebesar satu persen akan mengakibatkan meningkatnya nilai tukar rupiah sebesar 0.3599 persen, dan terjadinya depresiasi nilai tukar bath sebesar satu persen akan berdampak pada menguatnya nilai tukar rupiah sebesar 0.0306 persen.

Dari perhitungan di atas juga dapat diketahui menguatnya nilai tukar rupiah sebesar satu persen akan mengakibatkan meningkatnya indeks harga Indonesia sebesar 0.2755 persen, meningkatnya indeks harga Thailand sebesar satu persen akan mengakibatkan menurunnya indeks harga saham Indonesia sebesar 6.561persen, dan terjadinya depresiasi nilai tukar bath sebesar satu persen akan berdampak pada meningkatnya indeks harga saham Indonesia sebesar 1.069 persen.

\subsection{Analisis Sensitifitas dengan Perubahan Variabel Eksogen}

Dari hasil estimasi model koreksi kesalahan, di bawah ini akan dicoba melihat sensitifitas parameter yang dihasilkan dalam model dengan menggunakan simulasi perubahan variabel indeks harga Thailand dan nilai tukar bath terhadap dolar Amerika. Dalam hal ini shock akan diterapkan dengan meningkatkan atau menurunkan sebesar persentase tertentu pada kondisi pasar modal dan nilai tukar yang dijadikan sebagai variabel eksogen. Simulasi akan dimulai dengan perubahan 1 persen, 5 persen dan 10 persen baik naik maupun turun. Alasan nilai 10 persen digunakan sebagai angka perubahan tertinggi adalah karena di pasar modal biasanya perubahan maksimal sebesar 10 persen adalah perubahan yang sangat fatal karena perubahan di atas angka itu secara psikologis pasar modal tersebut sudah dianggap tidak kredibel. Dari hasil analisis dapat ditunjukkan bahwa secara umum rata-rata peningkatan maupun penurunan dengan menggunakan tingkat perubahan yang berbeda , menghasilkan 
kondisi yang tidak jauh berbeda dengan kondisi semula, baik menggunakan analisis sensitifitas dengan pengujian Engle Granger two step prosedure, kointegrasi Johansen maupun persamaan dengan Error Correction Model. Hal ini mengindikasikan bahwa parameter yang dihasilkan pada estimasi menggunakan pengujian kointegrasi maupun model koreksi kesalahan dapat diterima.

Tabel 11.

Hasil Analisis Sensitifitas Peningkatan Indeks Harga Saham Thailand dan Kurs Bath sebesar 1\%, $5 \%$ dan $10 \%$

\begin{tabular}{|c|c|c|c|}
\hline \multirow[t]{2}{*}{ Pengujian } & \multicolumn{3}{|c|}{ Peningkatan/Penurunan } \\
\hline & $1 \%$ & $5 \%$ & $10 \%$ \\
\hline $\begin{array}{l}\text { Kointegrasi dengan menggunakan Engle-Granger two- } \\
\text { step prosedure dengan Data Keseluruhan }\end{array}$ & stabil & stabil & stabil \\
\hline $\begin{array}{l}\text { Kointegrasi dengan menggunakan Engle-Granger two- } \\
\text { step prosedure dengan Data Sebelum Krisis }\end{array}$ & stabil & stabil & stabil \\
\hline $\begin{array}{l}\text { Kointegrasi dengan menggunakan Engle-Granger two- } \\
\text { step prosedure dengan Data Setelah Krisis }\end{array}$ & stabil & stabil & stabil \\
\hline $\begin{array}{l}\text { Kointegrasi Berdasarkan Johansen } \\
\text { Criterion(menggunakan data keseluruhan) }\end{array}$ & stabil & stabil & stabil \\
\hline $\begin{array}{l}\text { Kointegrasi Berdasarkan Johansen Criterion (menggu- } \\
\text { nakan data sebelum krisis) }\end{array}$ & stabil & stabil & stabil \\
\hline $\begin{array}{l}\text { Kointegrasi Berdasarkan Johansen Criterion (menggu- } \\
\text { nakan data setelah krisis) }\end{array}$ & stabil & stabil & stabil \\
\hline $\begin{array}{l}\text { Error Corection Model (ECM) } \\
\text { Periode Pengamatan Data Keseluruhan }\end{array}$ & stabil & stabil & stabil \\
\hline $\begin{array}{l}\text { Error Corection Model (ECM) } \\
\text { Periode Pengamatan Data Sebelum Crisis }\end{array}$ & stabil & stabil & stabil \\
\hline $\begin{array}{l}\text { Error Corection Model (ECM) } \\
\text { Periode Pengamatan Data Setelah Krisis }\end{array}$ & stabil & stabil & stabil \\
\hline
\end{tabular}

\section{PENUTUP}

\subsection{Simpulan}

1. Dari hasil pengujian kointegrasi dengan menggunakan Engle-Granger two step prosedure dan dengan data keseluruhan dapat dibuktikan bahwa adanya persamaan kointegrasi yaitu pengaruh besarnya indeks harga saham Indonesia, indeks harga saham Thailand, dan nilai tukar bath terhadap nilai tukar rupiah. Hasil pengujian kointegrasi dengan menggunakan metode Johansen Criterion juga terbukti mendukung hasil pengujian dengan menggunakan Engle-Granger two step procedure di mana masing-masing variabel saling berkointegrasi. 
2. Pengujian kointegrasi dengan menggunakan pembagian periode pengamatan, yaitu periode sebelum krisis dan periode krisis dengan menggunakan pengujian di atas, hasilnya sedikit berbeda yaitu jika digunakan EngleGranger two step prosedure ditemukan bahwa periode setelah krisis ada satu persamaan yang berkointegrasi, tetapi dengan menggunakan pengujian Johansen Criterion ditemukan bahwa semua persamaan terbukti berkointegrasi.

3. Dengan menggunakan estimasi persamaan regresi dengan model koreksi kesalahan (ECM/Error Correction Model), terbukti bahwa estimasi persamaan regresi yang menggunakan periode sebelum krisis terbukti tidak Iolos dalam pengujian Goodness of fit, sehingga tidak dapat dianalisis lebih lanjut. Hal ini tidak sejalan dengan hasil pengujian kointegrasi dengan menggunakan Johansen Criterion.

4. Dengan menggunakan periode krisis terbukti bahwa indeks harga Indonesia , indeks harga Thailand dan nilai tukar bath terbukti berpengaruh terhadap besarnya nilai tukar rupiah dalam jangka panjang. Demikian pula untuk estimasi persamaan pengaruh nilai tukar rupiah, indeks harga Thailand dan nilai tukar bath terhadap besarnya indeks harga saham Indonesia.

5. Hasil pengujian sensitifitas dengan shock masing-masing 1\%,5\% dan $10 \%$ juga membuktikan bahwa parameter yang dianalisis tebukti stabil.

\subsection{Saran}

Terjadinya hubungan jangka panjang antara variabel indeks harga dan nilai tukar baik Thailand maupun Indonesia, menunjukkan bahwa perekonomian Indonesia masih rentan terhadap terjadinya krisis di negara lain. Langkah awal yang harus dilakukan oleh pemerintah adalah mengendalikan fluktuasi nilai tukar rupiah dan penciptaan iklim perekonomian yang kondusif akan sangat bermanfaat bagi bertahannya perekonomian indonesia dari krisis ekonomi yang disebabkan dari dalam negeri maupun luar negeri.

\section{DAFTAR PUSTAKA}

Ajayi,Ricard, A. and Mboja Mougoue, (1996), "On The Dinamyc Relation Between Stocks Prices and Exchange Rate"Journal of Financial Research,Vol XIX, No. 2, pages 193-207.

Bank Indonesia, Statistik Ekonomi dan Keuangan Indonesia, berbagai edisi. Laporan Tahunan Bank Indonesia, berbagai edisi.

Dornbusch, R. and S. Fisher, (1980), "Exchange Rate and The Current Account", dalam American Economics Review 70, hal.960-71.

Engle, Robert F, dan Granger, C.W.J. , (1987), "Cointegration and Error Correction : Representation, Estimation and Testing", Econometrica, Vol.55,No.2, march 1987, hal.251-279.

Frankel,J.A., (1983), "Monetary and Portfolio Balance Models of Exchange Rate Determination",dalam J.S. Bhandari and B.H. Putnam, eds: Economic interdependence and Flexible Exchange Rates, MIT Press, Cambrige,MA.

Ewing, Bradley T., dkk. , (1998), " Co-Movement of The Prime Rate, CD Rate, and The S\&P Financial Stock Index ", The Journal of Financial Research , Vol. XXI, No. 4, hal.469-482.

Granger, C.W.J., (1969), "Investigating Relation by Economics Models and Cross Spectoral Methods ", Econometrica, Vol. 37 No.3 , July, hal.424-438

(1986), "Development in The Study of Cointegrated Economic Variables ", Oxford Bulletin of Economics and Statistics, Vol. 48 No.3 , hal.213-228. 
, (1988), "Some Recent Development Concept of Causality", Journal of Econometrics, No 39.3 , hal.119-211.

Gujarati, Damodar N., (2003), Basic Econometrics, $4^{\text {rd }}$ Edd, Mc Graw- Hill International Editions, New York

Gupta, J.P., Allain Chevalier dan Fran Sayekt, (1999), "The Causality between Interest Rate, Exchange Rate and Stock Price in Emerging Markets : The Case of The Jakarta Stock Exchange", diakses dari www.ssrn. com tanggal 20 Juli 2007.

Hill,Hall, (1996), The Indonesian Economy since 1966; Shoutheas Asia's Emerging Giant, Cambrige University Press.

Hsiao, Cheng, (1979), "Autoregresive Modelling of Canadian Money and Income Data”, Journal of the American Statistical Association, Vol.74, No. 367, September, hal. 553-560.

Insukindro, (1991), "Regresi Linier Lancung dalam Analisis Ekonomi: Suatu Tinjauan dengan Satu Studi Kasus di Indonesia", Jurnal Ekonomi dan Bisnis Indonesia (JEBI), tahun VI,No.1, hal.1-18.

(1992), " Pembentukan Model dalam Penelitian Ekonomi ", Jurnal Ekonomi dan Bisnis Indonesia (JEBI), No. 1, Tahun VII, hal. 1-11.

(1999), "Pemilihan Model Ekonomi Empirik dengan Pendekatan Koreksi Kesalahan", Jurnal Ekonomi dan Bisnis Indonesia (JEBI), Vol. 14, No.1, hal. 1-8.

, (1993), Ekonomi Uang dan Bank: Teori dan Pengalaman di Indonesia, Edisi Pertama,BPFE, Yogyakarta.

Ma C.K, and G.W.Kao, (1990), "On Exchang Rate Changes and Stock Price Reaction", Journal of Business Finance and Accounting 17, hal.441-49.

Jones, Charles P., (1997), Investments : Analysis and Management, Sixth Edition, John Wiley \& Sons, New York.

Mishkin, Frederic S, (1996), "Understanding Financial Crisis: a Developing Countries Perspective”, Annual World Bank Conference on Development Economics.

, (1995), The Economics of Money, Banking and Financial Markets, $4^{\text {th }}$ Edition, Harper Collins College Publisher.

Setyastuti, Rini, (2003), “ Krisis Ekonomi dan Kausalitas Antara Fluktuasi Nilai Tukar, Tingkat suku Bunga dan Indeks harga Saham di Indonesia", Laporan Penelitian Dosen Muda, tidak dipublikasikan.

Saunders, Anthony, (1994), Financial Institution Management, IRWIN.

Sukmawati, Rini Setyastuti dan Edi Sutarta, (2003-2005), "Krisis Ekonomi dan Kointegrasi Pasar Modal : Perbandingan Negara Maju dan Berkembang", Laporan Penelitian RUKK Tahun I,II dan III, tidak dipublikasikan.

Thomas, R.L. , (1997), Modern Econometrics : An Introduction, Addison Wesley Logman, Harlow, hal.373-400.

Wibowo, Y. Santosa dan Gunawan, (1998) " Dampak Disintermediasi Kegiatan Bank terhadap Efektivitas Kebijakan Moneter”, Buletin Ekonomi Moneter dan Perbankan, hal 123-140. 